\title{
Molecular systematics of the genus Senecio L. I: Hybridization in a British polyploid complex
}

\author{
STEPHEN A. HARRIS \& RUTH INGRAM \\ Department of Biology and Preclinical Medicine, Sir Harold Mitchell Building, University of St Andrews, St Andrews, \\ Fife KY16 9TH, Scotland, U.K.
}

\begin{abstract}
A survey of chloroplast DNA and nuclear ribosomal DNA variation was conducted in the allohexaploid Senecio cambrensis, the putative introgressant $S$. vulgaris var. hibernicus and their parental taxa: $S$. vulgaris var. vulgaris and S. squalidus. Ribosomal DNA allowed the differentiation of the two parental taxa and supported the hybrid origin of $S$. cambrensis at three of the four sites sampled; at the fourth site, in Edinburgh, non-additive rDNA phenotypes were found. No evidence, for or against the introgressive origin of var. hibernicus was found. Chloroplast DNA analysis provided independent evidence for the dual origin of S. cambrensis in Wales and Scotland, although the two parental taxa could not be distinguished.
\end{abstract}

Keywords: allopolyploidy, Asteraceae, introgression, molecular variation, Senecio cambrensis, S. vulgaris.

\section{Introduction}

Senecio vulgaris L., the common groundsel, is one of the most widespread annual/ephemeral species in Britain. Two subspecies of $S$. vulgaris are formally recognized: ssp. vulgaris and ssp. denticulatus (O. F. Muell.) P. D. Sell. Senecio vulgaris ssp. vulgaris is the common weedy taxon, whilst ssp. denticulatus is rare in Britain, being confined to a few coastal sites. The work described in this report concerns ssp. vulgaris only, and attempts to assess the effects of interaction of this taxon with the introduced species, $S$. squalidus $L$.

Senecio squalidus, the Oxford Ragwort, was introduced into the Oxford Botanic Garden in the seventeenth century. Its subsequent escape and spread has been well documented (Druce, 1927; Kent, 1956; Crisp, 1972). It is now common in most areas south of the central valley of Scotland. Senecio squalidus establishes in open habitats and waste places, often growing in mixed populations with $S$. vulgaris, though it can persist into later stages of succession due to its perennial habit.

Senecio squalidus is diploid $(2 n=20)$ whereas $S$. vulgaris is tetraploid $(2 n=40)$. The two species can hybridize and produce either almost sterile triploid hybrids (Ingram et al., 1980) or fertile tetraploid hybrids (Taylor, 1984), although this latter type has been recorded only once from an artificial cross.
Two evolutionary events have occurred in Britain consequent upon the introduction of Senecio squalidus.

The first of these is the formation of an inland radiate groundsel, which has been designated var. hibernicus Syme $(2 n=40)$. Evidence has accumulated that var. hibernicus is of introgressive origin. The suggestion was initially based on historical (Druce, 1927; Crisp, 1972), morphological (Monaghan \& Hull, 1976) and cytological (Ingram et al., 1980) evidence. The alternative hypothesis was that a single gene mutation gave rise to this form (Stace, 1977). Very recently Abbott et al. (1992) have shown that an aspartate aminotransferase allele $A a t-3 c$, which is present at high frequency in British $S$. squalidus, is common in var. hibernicus but absent from British, Irish and mainland European monomorphic populations of var. vulgaris. This is strong evidence for an introgressive origin of var. hibernicus.

The second evolutionary event is the origin of an endemic hexaploid species, Senecio cambrensis Rosser $(2 n=60)$. In contrast to the origin of var. hibernicus the origin of $S$. cambrensis has never been in any real doubt. Following the discovery of $S$. cambrensis in Wales, Rosser suggested that it was an allohexaploid hybrid between $S$. vulgaris and $S$. squalidus (Rosser, 1955). Artificial crosses and morphological studies have since confirmed this interpretation of the origin of S. cambrensis (Taylor, 1984; Harland, 1954). More 
recently a population of $S$. cambrensis was discovered in Edinburgh, Scotland (Abbott et al., 1983). It was suggested that this population may represent either long distance dispersal of achenes ('seeds') or a second origin of the species in Scotland (Abbott et al., 1983). Ashton \& Abbott (1992) have used allozyme data to show that a dual origin of the species, in Wales and Scotland, has occurred.

The past decade has seen an increasing awareness of the potential of DNA to answer biosystematic questions (Palmer, 1987; Jorgensen \& Cluster, 1988). Two DNA sequences have proved to be particularly useful, the nuclear ribosomal genes (rDNA) and the chloroplast genome (cpDNA). The structure and arrangement of nuclear rDNA genes is well understood (Jorgensen \& Cluster, 1988). These genes are tandemly arranged and biparentally inherited.

Ribosomal DNA has not been used extensively as a marker for introgressive hybridization. A number of workers have suggested that rDNA, particularly the intergenic spacer subrepeats may be useful markers to follow introgression of nuclear DNA (Appels et al., 1986; Tremousaygue et al., 1988; McIntyre et al., 1988; Springer et al., 1989). The introgressive origin of a taxon might be expected to have one (or more) of three effects. (i) An increase in the level of rDNA diversity in the introgressed taxon compared to the non-introgressed taxon (Schaal et al., 1987). (ii) The presence in the population of at least some individuals with additive restriction profiles between the two presumptive parents (Arnold et al., 1990; Cordesse et al., 1990; Rieseberg et al., 1990). (iii) No effect at all due to the loss of rDNA loci from the introgressing taxon, in the introgressant.

Ribosomal RNA genes have been used to infer hybridity in a number of species (e.g. Doyle \& Doyle, 1988; Talbert et al., 1990; Doyle et al., 1985). In each case the supposed hybrid had the additive rDNA patterns of the two putative parents.

The Angiosperm chloroplast genome (cpDNA) is a small circular molecule which is usually inherited uniparentally through the maternal parent (Palmer, 1987). These features make cpDNA a potentially useful molecule for studying allopolyploid and introgressive speciation in plants. A number of studies have now used cpDNA to study introgression (Reiseberg et al., 1988; Reiseberg et al., 1990) and allopolyploidy (Palmer et al., 1983; Soltis \& Soltis, 1989; Doyle et al., 1990).

The aims of the present investigation were: (i) to attempt to confirm the introgressive origin of Senecio vulgaris ssp. vulgaris var. hibernicus using rDNA and cpDNA markers; and (ii) to attempt to confirm the independent hybrid origins of S. cambrensis in Wales and Scotland using rDNA and cpDNA markers.
Whereas the second of these two aims was achieved we were unable to confirm or deny the introgressive origin of var. hibernicus. This result demonstrates the need to consider many different approaches in an investigation of this nature. Interesting information has been obtained regarding the effect of hybridity on rDNA markers, which is being investigated further because it has implications for the interpretation of results from this type of study.

\section{Materials and methods}

\section{Plant material}

Achenes from single individuals of Senecio cambrensis, $S$. squalidus, $S$. vulgaris ssp. vulgaris var. hibernicus and $S$. vulgaris ssp. vulgaris var. vulgaris, representing 116 accessions (Table 1), were grown in $10 \mathrm{~cm}$ pots containing Arthur Bower universal compost. The plants were illuminated for $16 \mathrm{~h}$ per day using $400 \mathrm{~W}$ halogen or mercury lamps. Leaf material was harvested when the plants were 10-12 weeks old.

\section{DNA extraction and molecular methods}

Intact total DNA was extracted from leaf tissue according to the protocol of Hattori et al. (1987). Subsequently the protocol of Doyle \& Doyle (1987) was found to be effective when only very small quantities of plant material were available. The DNA was used for both the rDNA and cpDNA analysis. For the rDNA analysis total DNA was extracted from individual plants, whereas in the cpDNA analysis total DNA was extracted from a pooled sample of 10 plants, each having the same female parent.

One-microgram aliquots of total DNA were digested with 5-10 units of restriction enzyme, using a universal buffer [TA, $33 \mathrm{~mm}$ Tris-acetate ( $\mathrm{pH} 7.9), 66$ $\mathrm{mm}$ potassium acetate, $10 \mathrm{~mm}$ magnesium acetate, $4 \mathrm{~mm}$ spermidine tetrachloride, $0.5 \mathrm{~mm}$ dithiothreitol]. Each individual was treated with the battery of restriction enzymes as indicated in Table 1 . In the cpDNA analysis a total of 11 restriction enzymes were used; one tetranucleotide cutting enzyme (HaelII), 10 hexanucleotide cutting enzymes (BamHI, BgllI, EcoRI, EcoRV, HinDIII, KpnI, Pstl, SacI, XhoI) and one heptanucleotide cutting enzyme (BstEII). In the rDNA survey only three enzymes were used (BamHI, EcoRI, EcoRV).

Digested DNA samples were run on 1 per cent agarose gels at $40 \mathrm{~mA}$ overnight in a SEB gel buffer $(0.04 \mathrm{M}$ Tris- $\mathrm{HCl}, 0.02 \mathrm{M}$ sodium acetate, $1 \mathrm{~mm}$ disodium EDTA, pH 7.85), blotted on to Amersham Hybond C-banding using $20 \times$ SSC as the transfer buffer and baked for $2 \mathrm{~h}$ at $80^{\circ} \mathrm{C}$. DNA probes were 
labelled by the random primer method (Feinberg \& Vogelstein, 1983) using ${ }^{32} \mathrm{P}-\mathrm{dATP}(3000 \mathrm{Ci} / \mathrm{mm}, 10$ $\mu \mathrm{Ci})$. Hybridization took place overnight at $65^{\circ} \mathrm{C}$ in Buffer III [0.6 M sodium chloride, $10 \mathrm{~mm}$ PIPES ( $\mathrm{pH}$
6.8), 1 mM disodium-EDTA ( $\mathrm{pH} 8.5$ ), $10 \times$ Denhardt's solution]. Filters were washed for the cpDNA analysis according to Palmer (1986). The wash conditions for the rDNA analysis were: a brief rinse in $2 \times \mathrm{SSC}$ at

Table 1 Locations and numbers of individuals sampled in populations of Senecio cambrensis, S. squalidus, $S$. vulgaris ssp. vulgaris var. vulgaris and $S$. vulgaris ssp. vulgaris var. hibernicus. Figures in parentheses indicate the number of plants sampled. Total number of plants sampled is 116

\begin{tabular}{|c|c|c|}
\hline Location & Grid reference & Analysis* \\
\hline \multicolumn{3}{|l|}{ S. cambrensis } \\
\hline Brymbo, Wales (3) & SJ296539 & $\mathbf{r}(\mathbf{A}), c(\mathbf{A})$ \\
\hline Leith Docks, Edinburgh (1) & NT268765 & $r(A), c(0)$ \\
\hline Mochdre, Wales (3) & SH822791 & $\mathbf{r}(\mathbf{A}), \mathrm{c}(0)$ \\
\hline Salamander Street, Edinburgh (7) & NT276763 & $r(A), c(1)$ \\
\hline \multicolumn{3}{|l|}{ S. squalidus } \\
\hline Brymbo, Wales (1) & SJ296539 & $\mathbf{r}(\mathrm{A}), \mathrm{c}(\mathrm{A})$ \\
\hline Cardiff, Wales (3) & ST173733 & $\mathrm{r}(\mathrm{A}), \mathrm{c}(0)$ \\
\hline Grangemouth, Scotland (3) & NS977814 & $\mathbf{r}(\mathbf{A}), \mathrm{c}(0)$ \\
\hline Leith Docks, Edinburgh (11) & NT268765 & $\mathbf{r}(\mathbf{A}), \mathrm{c}(0)$ \\
\hline Mochdre, Wales (3) & SH822781 & $r(A), c(0)$ \\
\hline Lincoln $(4)$ & SK971710 & $\mathbf{r}(\mathrm{A}), \mathrm{c}(0)$ \\
\hline Sheffield (2) & SK350870 & $r(A), c(1)$ \\
\hline York $(7)$ & SE590510 & $\mathbf{r}(\mathbf{A}), \mathrm{c}(1)$ \\
\hline Stoke $(1)$ & SP360780 & $\mathrm{r}(0), \mathrm{c}(1)$ \\
\hline Salamander Street, Edinburgh (1) & NT276763 & $\mathbf{r}(0), c(1)$ \\
\hline \multicolumn{3}{|l|}{ S. vulgaris var. vulgaris $(\mathbf{M})$} \\
\hline Bo'Ness, Scotland (1) & NS990810 & $r(A), c(0)$ \\
\hline Cambridge (4) & TL460580 & $\mathbf{r}(\mathrm{A}), \mathrm{c}(0)$ \\
\hline Lincoln $(1)$ & SK970710 & $\mathbf{r}(\mathrm{A}), \mathrm{c}(0)$ \\
\hline Migvie, Scotland (1) & NJ437068 & $\mathrm{r}(\mathrm{A}), \mathrm{c}(1)$ \\
\hline Puffin Island, Wales (2) & SH653824 & $\mathbf{r}(\mathrm{A}), \mathrm{c}(0)$ \\
\hline St Andrews, Scotland (8) & NO484162 & $\mathbf{r}(\mathrm{A}), \mathrm{c}(0)$ \\
\hline York $(4)$ & SE605508 & $\mathbf{r}(\mathbf{A}), \mathrm{c}(1)$ \\
\hline \multicolumn{3}{|l|}{ S. vulgaris var. vulgaris $(\mathrm{P})$} \\
\hline Brymbo, Wales (3) & SJ296539 & $r(A), c(3)$ \\
\hline Lincoln $(1)$ & SK970710 & $\mathbf{r}(\mathrm{A}), \mathrm{c}(0)$ \\
\hline Grangemouth, Scotland (5) & NS977814 & $r(A), c(0)$ \\
\hline Leith Docks, Edinburgh, (3) & NT268765 & $\mathrm{r}(\mathrm{A}), \mathrm{c}(0)$ \\
\hline Mochdre, Wales (2) & SH822791 & $r(A), c(1)$ \\
\hline Salamander Street, Edinburgh (4) & NT276763 & $\mathbf{r}(\mathbf{A}), c(1)$ \\
\hline \multicolumn{3}{|l|}{ S. vulgaris var. hibernicus $(\mathbf{P})$} \\
\hline Lincoln $(1)$ & SK970710 & $r(A), c(0)$ \\
\hline Grangemouth, Scotland (5) & NS977814 & $\mathbf{r}(\mathbf{A}), \mathrm{c}(0)$ \\
\hline Leith Docks, Edinburgh (3) & NT268765 & $\mathbf{r}(\mathbf{A}), \mathrm{c}(0)$ \\
\hline Mochdre, Wales (1) & SH822791 & $\mathrm{r}(\mathrm{A}), \mathrm{c}(1)$ \\
\hline Newcraighall, Edinburgh (6) & NT270730 & $\mathbf{r}(\mathbf{A}), \mathrm{c}(0)$ \\
\hline Salamander Street, Edinburgh (7) & NT276763 & $r(A), c(1)$ \\
\hline York ('RJA') $(11)$ & SE590510 & $\mathrm{r}(\mathrm{A}), \mathrm{c}(1)$ \\
\hline York ('Warr') (3) & SE605508 & $\mathbf{r}(\mathrm{A}), \mathrm{c}(0)$ \\
\hline Brymbo, Wales $(1)$ & SJ296539 & $r(A), c(1)$ \\
\hline
\end{tabular}

*' $r$ ' indicates rDNA analysis and ' $c$ ' indicates cpDNA analysis. The number in parentheses indicates the number of individuals analysed, while ' $A$ ' indicates all. Herbarium vouchers of all material have been deposited at StA. 
room temperature followed by a 20 -min wash in $1 \times \mathrm{SSC}+0.1$ per cent SDS at $65^{\circ} \mathrm{C}$ and a subsequent 25 -min wash in $0.3 \times \mathrm{SSC}+0.1$ per cent $\mathrm{SDS}$ at $65^{\circ} \mathrm{C}$.

\section{Probe characteristics}

Two types of chloroplast probes were used in this study; (i) cloned Lactuca sativa cpDNA fragments (Jansen \& Palmer, 1987) and (ii) total L. sativa cpDNA. Cloned cpDNA probes were used either singly $(\mathrm{C} 1, \mathrm{C} 2, \mathrm{C} 4, \mathrm{C} 6, \mathrm{C} 7, \mathrm{C} 9, \mathrm{C} 15)$ or as a mixture (C5a-C5c; C10-C11-C12; C13-C14). These probes sampled approximately 80 per cent of the Senecio chloroplast genome. The remainder of the genome was sampled using total cpDNA as a probe. Total cpDNA was prepared from lettuce, according to the method of Palmer (1986). The purified cpDNA was digested with EcoRI prior to labelling.

A cloned nuclear ribosomal DNA repeat from Triticum aestivum 'Chinese Spring' was used to locate ribosomal sequences in the Senecio nuclear genome. The probe, pTA71, is a complete rDNA repeat of 9.1 kb cloned into an EcoRI site of pUC19 (Gerlach \& Bedrook, 1979).

\section{Results}

Molecular variation in Senecio vulgaris ssp. vulgaris s.l.

Intraspecific DNA variation was identified in both the nuclear (rDNA) and chloroplast genomes (Fig. 1, Tables 2-3) of Senecio vulgaris var. vulgaris and var. hibernicus.

Variation in the rDNA was identified with $E c o$ RV $(2$ phenotypes; V-1 and $\mathrm{V}-4$ ) and BamHI (3 phenotypes; B-1, B-2, B-3). No variation was found with EcoRI. Shannon-Weaver diversity estimates were calculated (Table 2) for the polymorphic enzymes and $t$-tests conducted according to Hutcheson (1970). No significant differences $(P=0.05)$ were found between monomorphic and polymorphic populations of $S$. vulgaris var. vulgaris $($ Eco RV, $t=0.43$, d.f. $=34 ;$ BamHI, $t=0.15$, d.f. $=33$ ), between $S$. vulgaris var. vulgaris s.l.

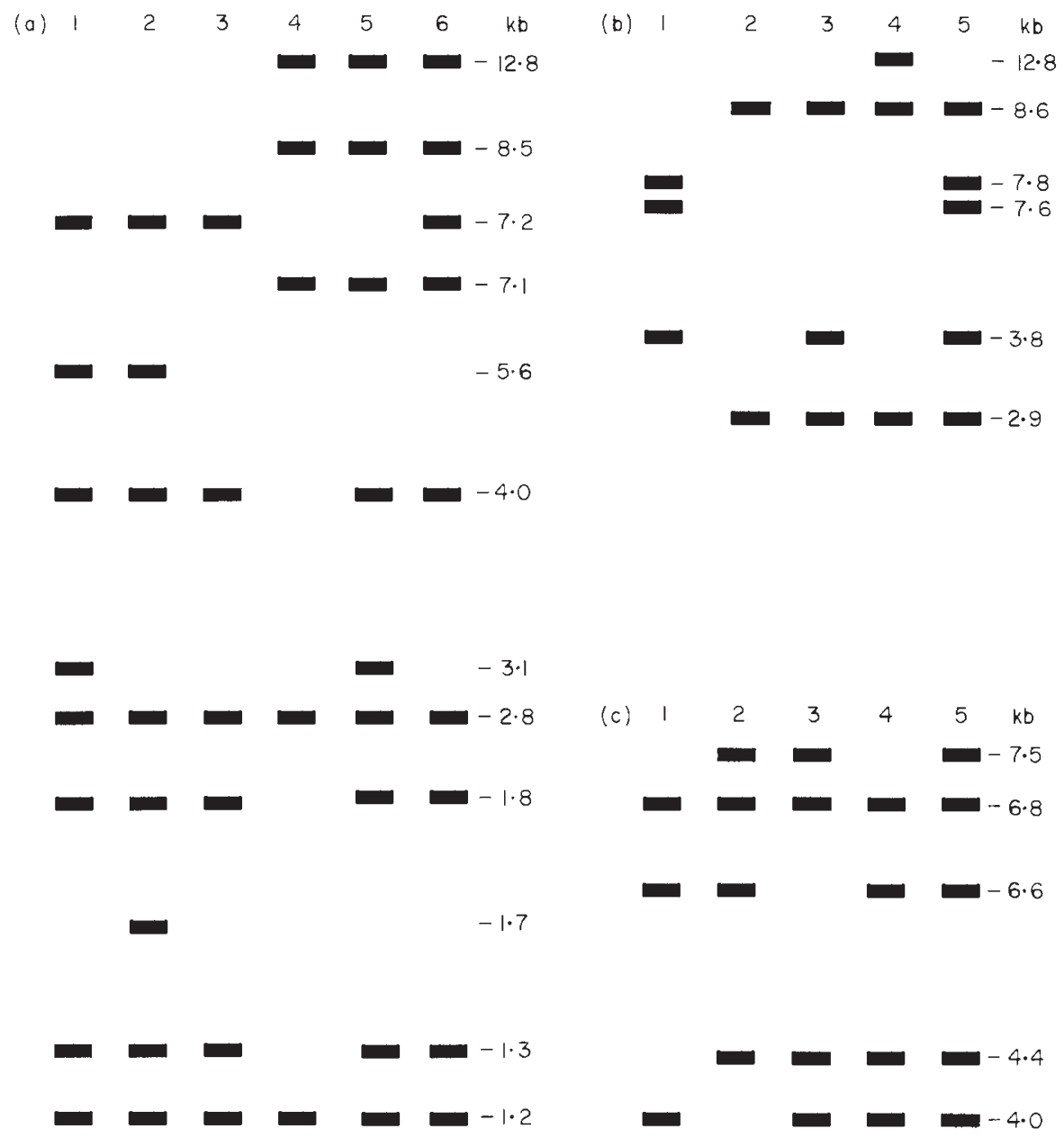

Fig. 1 Range of rDNA phenotypes identified in various Senecio taxa when total DNA, digested with either (a) $B a m \mathrm{HI}$, (b) EcoRI or (c) EcoRV, is probed with pTA71. 
Table 2 Frequencies of rDNA phenotypes found in various Senecio species and identified with (a) EcoRI, (b) EcoRV and (c) BamHI. Shannon-Weaver diversity estimates $[I s]$ and variances $[V(I S)]$ are given

\begin{tabular}{|c|c|c|c|c|c|c|c|c|c|c|}
\hline \multirow[b]{2}{*}{ Taxon* } & \multirow{2}{*}{$\begin{array}{l}\text { Number of } \\
\text { populations }\end{array}$} & \multirow{2}{*}{$\begin{array}{l}\text { Number of } \\
\text { individuals }\end{array}$} & \multicolumn{8}{|c|}{ Phenotype number } \\
\hline & & & 1 & 2 & 3 & 4 & 5 & 6 & Is & $\mathrm{V}(\mathrm{Is})$ \\
\hline \multicolumn{11}{|l|}{ EcoRI } \\
\hline S. cambrensis & 4 & 13 & 0.39 & - & - & - & 0.62 & - & 0.96 & 0.22 \\
\hline $\begin{array}{l}\text { S. squalidus } \\
\text { S. vulgaris }\end{array}$ & 8 & 26 & - & 0.50 & 0.39 & 0.12 & - & - & 1.39 & 0.06 \\
\hline var. vulgaris $(\mathrm{M})$ & 7 & 11 & 1.00 & - & - & - & - & - & 0.00 & 0.00 \\
\hline var. vulgaris $(\mathbf{P})$ & 6 & 14 & 1.00 & - & - & - & - & - & 0.00 & 0.00 \\
\hline var. vulgaris s.l. & 13 & 25 & 1.00 & - & - & - & - & - & 0.00 & 0.00 \\
\hline var. hibernicus & 9 & 29 & 1.00 & - & - & - & - & - & 0.00 & 0.00 \\
\hline \multicolumn{11}{|l|}{ EcoRV } \\
\hline S. cambrensis & 4 & 13 & 0.39 & - & - & - & 0.62 & - & 0.96 & 0.05 \\
\hline $\begin{array}{l}\text { S. squalidus } \\
\text { S. vulgaris }\end{array}$ & 8 & 22 & - & 0.68 & 0.32 & - & - & - & 0.90 & 0.03 \\
\hline var. vulgaris $(\mathbf{M})$ & 7 & 19 & 0.90 & - & - & 0.11 & - & - & 0.49 & 0.06 \\
\hline var. vulgaris $(\mathbf{P})$ & 6 & 16 & 0.94 & - & - & 0.06 & - & - & 0.34 & 0.06 \\
\hline var. vulgaris s.l. & 13 & 35 & 0.91 & - & - & 0.09 & - & - & 0.42 & 0.03 \\
\hline var. hibernicus & 9 & 31 & 0.81 & - & - & 0.19 & - & - & 0.71 & 0.03 \\
\hline \multicolumn{11}{|l|}{ BamHI } \\
\hline S. cambrensis & 4 & 12 & 0.50 & - & - & - & 0.08 & 0.42 & $1 \cdot 32$ & 0.17 \\
\hline $\begin{array}{l}\text { S. squalidus } \\
\text { S. vulgaris }\end{array}$ & 8 & 30 & - & - & - & 1.00 & - & - & 0.00 & 0.00 \\
\hline var. vulgaris $(\mathbf{M})$ & 7 & 16 & 0.81 & 0.13 & 0.06 & - & - & - & 0.87 & 0.13 \\
\hline var. vulgaris $(\mathbf{P})$ & 6 & 18 & 0.78 & 0.17 & 0.06 & - & - & - & 0.94 & 0.10 \\
\hline var. vulgaris s.l. & 13 & 34 & 0.76 & 0.15 & 0.09 & - & - & - & 1.01 & 0.03 \\
\hline var. hibernicus & 9 & 33 & 0.54 & 0.45 & 0.01 & - & - & - & 1.02 & 0.05 \\
\hline
\end{tabular}

${ }^{*} \mathrm{M}=$ Monomorphic populations, $\mathrm{P}=$ Polymorphic populations.

and var. hibernicus (EcoRV, $t=1.18$, d.f. $=66 ; B a m \mathrm{HI}$, $t=0.02$, d.f. $=62$ ) and between monomorphic var. vulgaris and var. hibernicus populations $($ Eco RV, $t=0.77$, d.f. $=38 ; B a m \mathrm{HI}, t=0.35$, d.f. $=29)$.

Eight polymorphic cpDNA probe-enzyme combinations (PECs) were found in ssp. vulgaris s.l. These were found in both varieties and none were found which were unique to var. hibernicus.

The absence of additive rDNA patterns between Senecio vulgaris var. vulgaris and $S$. squalidus in var. hibernicus and the lack of an increase in the rDNA diversity of var. hibernicus compared to var. vulgaris will be discussed in the light of the results obtained from S. cambrensis.

\section{Molecular variation in Senecio squalidus}

Intraspecific DNA variation was identified in both the nuclear (rDNA) and chloroplast genomes (Fig. 1, Tables 2-3) of Senecio squalidus. Variation in the rDNA was identified with EcoRI (three phenotypes;
I-2, I-3, I-4) and EcoRV (two phenotypes; V-2, V-3). No variation was found with $B a m H I$.

Nine polymorphic cpDNA PECs were found in Senecio squalidus. Of these, three were found to be unique to a single line of $S$. squalidus (Sheffield).

\section{Molecular variation in Senecio cambrensis}

The hybrid nature of Senecio cambrensis from Wales (Mochdre and Brymbo) and Scotland (Leith Docks) was confirmed by the presence of additive rDNA restriction profiles for $B a m H I, E c o R I$ and EcoRV (B-5, B-6, I-5, V-5. Fig. 1, Table 2). The hybrid nature of S. cambrensis from Salamander Street (Scotland) could not be confirmed as additive $E c o$ RI and $E c o$ RV patterns were found for only one out of six individuals. In all cases the $S$. vulgaris s.l. phenotype was found for $E c o$ RI (I-1) and EcoRV (V-1). All individuals from this population showed $S$. vulgaris s.l. type BamHI phenotypes (B-1) including the individual which was additive for EcoRI and EcoRV. 
Table 3 Polymorphic cpDNA probe-enzyme combinations in Senecio cambrensis (c), S. squalidus (s), S. vulgaris ssp. vulgaris var. vulgaris (v), $S$. vulgaris ssp. vulgaris var. hibernicus $(\mathbf{h})$

\begin{tabular}{|c|c|c|c|c|c|c|c|}
\hline \multirow[b]{2}{*}{ Enzyme } & \multirow[b]{2}{*}{ Probe } & \multicolumn{2}{|l|}{ State ${ }_{\dagger}^{\dagger}$} & \multicolumn{4}{|c|}{ Taxa* } \\
\hline & & A & B & $c$ & $\mathrm{~h}$ & $s$ & $\mathrm{v}$ \\
\hline BamHI & C6 & - & 5.70 & & & & $*$ \\
\hline BamHI & C6 & 5.38 & 5.70 & $*$ & & & \\
\hline$B g l I I$ & C6 & 2.95 & 3.31 & $*$ & & & \\
\hline BstEII & $\mathrm{C} 4$ & 2.95 & 3.31 & $*$ & & $*$ & \\
\hline EcoRI & $\mathrm{C} 4$ & - & $3.00,2.00,1.70$ & & & $*$ & \\
\hline EcoRI & $\mathrm{C} 4$ & - & $3.00,1.70$ & & & & $*$ \\
\hline EcoRI & C6 & 1.2 & - & $*$ & $*$ & & \\
\hline EcoRI & C6 & - & $2.50,2.10$ & & & $*$ & \\
\hline EcoRl & C6 & - & 1.40 & & & $*$ & \\
\hline EcoRI & $\mathrm{C} 7$ & - & $1.40,0.77$ & & & $*$ & * \\
\hline HaeIII & C6 & 2.3 & $2.10+(0.20)$ & & & $*$ & \\
\hline HaeIII & $\mathrm{C} 15$ & 1.4 & - & $*$ & & $*$ & \\
\hline EcoRV & C6 & 3.30 & - & & $*$ & $*$ & * \\
\hline HinDIII & C10-C12 & 11.30 & $6.00+4.80$ & $*$ & $*$ & & * \\
\hline SacI & C6 & - & 4.80 & $*$ & & $*$ & * \\
\hline SacI & C6 & 3.11 & 3.50 & $*$ & & & \\
\hline XhoI & $\mathrm{C} 7$ & - & 2.30 & & $*$ & & $*$ \\
\hline
\end{tabular}

†Indicates fragment differences. Where ' $\mathrm{A}$ ' and ' $\mathrm{B}$ ' are the changes which occur within the taxa indicated. '-' fragment absent and fragments in parentheses are hypothesized fragments beyond the resolution limit of assay system. *Distribution of polymorphic states ('A' and 'B') among Senecio taxa. $\mathrm{c}=S$. cambrensis, $\mathrm{h}=S$. vulgaris $\mathrm{ssp}$. vulgaris var. hibernicus $\mathrm{s}=S$. squalidus and $\mathrm{v}=S$. vulgaris $\mathrm{ssp}$. vulgaris var. vulgaris.

Results of experimental reciprocal crosses between Senecio squalidus and $S$. vernalis Waldst. \& Kit. have shown that cpDNA in Senecio is inherited through the maternal parent (Harris, 1990). The lack of variation between the cpDNAs of $S$. vulgaris ssp. vulgaris s.l. and $S$. squalidus made it impossible to identify the maternal parent of the allohexaploid hybrid, with the probeenzyme combinations used in this study. Some insight may, however, be obtained from the observation that the C10/11/12-HinDIII polymorphism was found in $S$. vulgaris ssp. vulgaris s.l. but was absent from $S$. squalidus. The presence of this polymorphism in Scottish $S$. cambrensis suggests that, at least in this location, the maternal parent was $S$. vulgaris ssp. vulgaris s.l..

Although the maternal parentage of Senecio cambrensis could not be identified in both populations, the two populations analysed for cpDNA variation could be distinguished on the basis of the only length mutation identified in this study (Fig. 2). The length mutation, approximately $350 \mathrm{bp}$, was identified with the probe $\mathrm{C} 6$ and the restriction enzymes $B a m \mathrm{HI}, B g I I I$ and SacI. The length mutation was found in Welsh $S$. cambrensis (Brymbo) but was absent from Scottish $S$. cambrensis (Salamander Street) and all of the geographically separated populations of the two parental species which were analysed. The occurrence of this mutation is an important marker in $S$. cambrensis because it strongly suggests that the Welsh and Scottish populations had separate origins.

\section{Differentiation of the taxa}

A total of 16 phenotypes were identified with the three restriction enzymes used in the rDNA analysis (Fig. 1). Senecio vulgaris s.l. and $S$. squalidus could readily be differentiated on the basis of their rDNA phenotypes with each of the enzymes used (Table 2). Thus rDNA phenotypes produced by BamHI, EcoRI and EcoRV are useful markers to distinguish the DNA of $S$. vulgaris s.l. Analysis of the rDNA using the single cutting enzyme $X b a$ I has shown that a single rDNA repeat length of approximately $15 \mathrm{~kb}$ is found in $S$. vulgaris s.l., while in $S$. squalidus two repeat lengths are found, one of approximately $14.1 \mathrm{~kb}$ and the other of approximately $12.8 \mathrm{~kb}$ (Harris, 1990). In both cases no evidence of intraspecific variation in repeat length was found. Intraspecific variation was identified with BamHI and EcoRV in S. vulgaris ssp. vulgaris s.l. and with EcoRI and EcoRV in S. squalidus. The intraspecific variation which we have encountered is probably a result of site mutations and, therefore, each enzyme may be treated as identifying an independent change.

In contrast to the rRNA genes it proved impossible to differentiate Senecio vulgaris s.l. and S. squalidus on the basis of their respective chloroplast genomes, even when up to 11 enzymes were used (cloned cpDNA probes, 11 enzymes; total cpDNA, nine enzymes). Intraspecific cpDNA variation was encountered (Table 4) although the range of variation found was encompassed by both taxa. At least one of these polymorphisms has previously been reported. Bleyden (1988) reports that a $10.2 \mathrm{~kb}(11.3 \mathrm{~kb}$ in this study) HinDIII fragment is associated with triazine-susceptible $S$. vulgaris biotypes while a single site mutation producing two fragments, $5.6 \mathrm{~kb}$ an $4.3 \mathrm{~kb}(6.0$ and $4.8 \mathrm{~kb}$ this study) respectively, is associated with a triazineresistant biotype. This polymorphism was absent in all of the $S$. squalidus populations which were examined.

\section{Discussion}

The origin of var. hibernicus

The rDNA restriction pattern phenotypes of Senecio vulgaris s.l. and S. squalidus differ and therefore the 
Fig. 2 Bam HI-digested total Senecio DNA probed with Lactuca sativa cpDNA probe C6. Lanes 1,8 , 9-Welsh S. cambrensis; lanes 2, $3-S$. vulgaris $\mathrm{ssp}$. vulgaris s.l.; lanes 4 , $5-S$. squalidus; 6,7 -Scottish $S$. cambrensis, ' $\mathrm{L}$ ' - position of the $350 \mathrm{bp}$ length mutation.

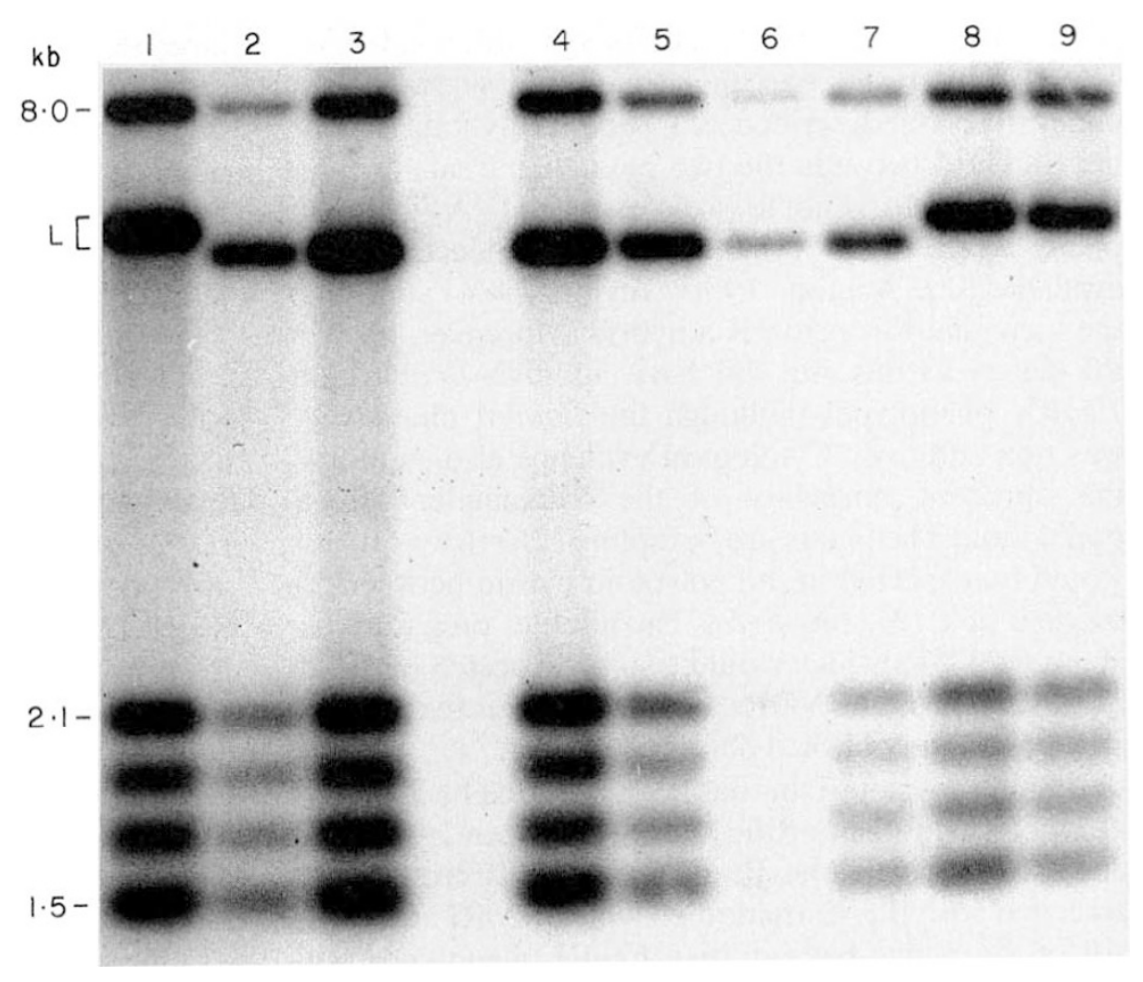

potential exists for tracing introgression between these two species. In the introduction it was pointed out that the effect of such introgression would depend on circumstances.

The first possibility would be an increase in rDNA diversity in var. hibernicus compared to var. vulgaris. Diversity estimates have shown that no such increase can be traced in the present case.

The second possibility would be the presence of at least some individuals of var. hibernicus with additive rDNA phenotypes. Again no such additive phenotypes were traced, although we have demonstrated that additive rDNA phenotypes are not always identified, even when known hybrid genomes are analysed. This point is discussed below.

The third possibility is that the rDNA from one of the parental taxa is lost in var. hibernicus due to random events so that introgression is again not detectable.

In the present example, isozyme data provide very good evidence of an introgressive origin of var. hibernicus (Abbott et al., 1992). Therefore the conclusion must be that rDNA analysis is less suitable than isozyme analysis for tracing introgression in this particular case, even though the two parental taxa have easily distinguishable rDNA phenotypes.

One possible hypothesis is that the rDNA of the Senecio squalidus genome was lost early in introgression. The initial hybrid between $S$. squalidus and $S$. vulgaris ssp. vulgaris is likely to have been triploid $(2 n=3 x=30)$, with two arrays of $S$. vulgaris rRNA and one array of $S$. squalidus genes. Ingram et al. (1980) demonstrated that rare functional gametes from the largely sterile hybrid were more or less diploid because the backcross offspring from the triploid hybrid were approximately tetraploid. If at this stage the two $S$. vulgaris arrays were included in the functional gamete with either the exclusion of the whole $S$. squalidus chromosome or the loss of the whole $S$. squalidus rDNA array, then neither an additive pattern nor an increase in rDNA diversity would be expected in var. hibernicus. This scenario is best explained if var. hibernicus is the result of a single or few introgression events.

\section{The origin of Senecio cambrensis}

The rDNA evidence supports a hybrid origin for Senecio cambrensis between $S$. vulgaris ssp. vulgaris and $S$. squalidus; a similar conclusion has been reached from studies based on cytology (Rosser, 1955), morphology (Taylor, 1984) and allozymes (Ashton \& Abbott, 1992).

This investigation of Senecio cambrensis has, however, generated a very interesting result for a population at Salamander Street in Edinburgh. In this population only one out of six accessions showed an additive rDNA phenotype for $E c o$ RI and EcoRV. The other five accessions (and the BamHI phenotype of the above accession) showed profiles which were 
compatible with $S$. vulgaris ssp. vulgaris only (i.e. I-1:V$1: \mathrm{B}-1)$. This result was unexpected and suggests that either the taxon described as S. cambrensis at this site is not a hybrid between the two putative parents or that the $S$. squalidus genome (at least the rDNA) in these plants is effectively absent. All the evidence that is available (e.g. Ashton, 1990; Taylor, 1984) supports the view that this taxon is a hybrid. Moreover, one of the plants at this site did have additive EcoRI and EcoRV phenotypes (although the BamHI phenotype was non-additive). Cytological evidence also supports the apparent normality of the Salamander Street population. The plants are hexaploid $(2 n=6 x=60)$, as would be expected in the polyploid hybrid between $S$. vulgaris and $S$. squalidus. Favourable preparations show six NORs which would also be expected because $S$. vulgaris has four NORs and $S$. squalidus two NORs (R. Ingram, unpublished data).

A similar result to this has been reported by Zimmer et al. (1988) for an artificial cross between Zea mays and $Z$. luxurians. The $F_{1}$ progeny of this cross were screened with the restriction enzymes EcoRI and Sst I. All of the plants had additive EcoRI phenotypes but four out of the 12 individuals tested had only the $Z$. mays SstI phenotype. That is, some of the $\mathrm{F}_{1}$ hybrids apparently lacked the rRNA genes from $Z$. luxurians when tested with one enzyme $(S s t I)$ but not the other (EcoRI). No explanation for this phenomenon was suggested other than that there was a need to know more about the inheritance of rDNA. Fabijanski et al. (1990) report the presence of non-additive phenotypes in hexaploid Avena species using a random repeat sequence probe.

In Senecio cambrensis non-additive phenotypes have been obtained for most individuals of one population unlike the situation in Zea, where some additive phenotypes were found. There is, however, no evidence to suggest that if more enzymes were used, additive phenotypes would not be obtained. If the hybrid nature of $S$. cambrensis from Salamander Street is accepted, then two possible suggestions may be put forward. (i) Some Senecio squalidus plants at the Salamander Street site possessed $S$. vulgaris type rDNA phenotypes (either as a rare rDNA phenotype or to the exclusion of other phenotypes). Following the hybridization event, rare rDNA phenotypes were amplified in some lines but not in others. (ii) The $S$. squalidus rDNA is heavily methylated and therefore not available for digestion by methylation-sensitive enzymes (Flavell et al., 1986), all of the enzymes which were used in the rDNA study were methylation sensitive.

Nothing is known regarding the rDNA phenotypes of Salamander Street Senecio squalidus. It is, however, difficult to believe that accessions from this site would have radically different rDNA phenotypes from the other $S$. squalidus accessions examined. The presence of a rare rDNA with a similar phenotype to that of S. vulgaris may be possible, but one would have to envisage a rapid amplification and fixation of an originally rare vulgaris-type $S$. squalidus rDNA variant (in a period of approximately 20 years; Abbott et al., 1983).

The digests of Senecio cambrensis from Salamander Street revealed a smear of high molecular weight DNA at the top of the autoradiograph. This probably indicates sequences that share sequence similarity with the rDNA probe but are not cut due to methylation. It is not possible to distinguish those rDNA sequences which come from $S$. vulgaris and those which come from $S$. squalidus, without a more specific probe. It would seem likely that the explanation for nonadditive rDNA phenotypes in Salamander Street $S$. cambrensis is the result of variable site methylation between the two genomes. However, this does not explain why variable site methylation should occur at this location and not at others.

This study provides an additional example of the failure to detect the rDNA of a taxon, which other data suggests ought to be present.

'RJA' is a collection of var. hibernicus from York which has been shown isozymically and morphometrically to be more 'squalidus-like' than other var. hibernicus populations (Irwin, 1990). Even this population, which presumably has arisen in the recent past ('Seed' collected in 1979), shows no evidence of $S$. squalidus rDNA being present, which is in contrast to the isozyme and morphological data. If as Irwin (1990) suggests, 'RJA' is the result of fusion between an unreduced $S$. squalidus gamete and a haploid $S$. vulgaris gamete one would expect an additive rDNA restriction pattern.

The absence of any differentiation between the cpDNAs of Senecio vulgaris and $S$. squalidus means that the maternal parent of $S$. cambrensis could not be determined. However the presence of a unique $350 \mathrm{bp}$ length mutation in the chloroplast genome of Welsh $S$. cambrensis has proved to be of considerable interest.

This length mutation present in Welsh Senecio cambrensis could have arisen in two ways, either it occurred during (or shortly after) the initial hybridization event or it was present in the parental material.

Crisp (1972) left the question of the date of origin of Senecio cambrensis open. However, Abbott et al. (1983) have suggested that $S$. cambrensis originated in Wales between 1910 and 1925. If the length mutation occurred during or shortly after the initial hybridization event then it must have become fixed in the population within 80 years. Fixation of cpDNA mutations is 
likely to be a very rare event, as a result of the large number of cpDNA molecules per cell and the low mutation rate (Birky et al., 1983; Klekowski, 1988). Whether the mutation occurred in the initial triploid hybrid between $S$. squalidus and $S$. vulgaris ssp. vulgaris s.l. or following chromosome doubling cannot be identified. It could perhaps, be postulated that the presence of a partially foreign nucleus in a native cytoplasm could create some instability in the native cpDNA. Frankel et al. (1979) have reported changes in the cpDNA during two interspecific cytoplasm introgressions in Nicotiana. However, Galau \& Wilkins (1989) have conducted a study into the effects of cpDNA of transferring plastids from Gossypium harknessii into $G$. hirsutum and G. barbadense nuclear backgrounds. After 13 successive backcross generations there were no changes in the 136 restriction fragments examined.

Tragapogon contains two examples of recent allopolyploid speciation, T. mirus and T. miscellus. These species probably originated about 50 years ago in North America. In each case the cytoplasms of the allopolyploid species were identical to one of the parental species (Soltis \& Soltis, 1989). Even over much longer time scales the cpDNA of allopolyploids appears to be very stable (Aegilops triuncialis; Murai and Tsunewaki, 1984). However, in the case of the amphidiploid Brassica napus, the cpDNA was found to be different to the putative maternal parent, B. oleracea (Palmer et al., 1983).

Length mutations are rare events (Palmer, 1987). Due to the potential rarity of the initial mutation event and its fixation in a population in a short period of time, the most likely explanation is that one of the parental taxa carries a length mutation which has not yet been located due to the limited size of the survey. To address this fascinating problem it will be necessary to undertake more extensive sampling of Senecio cambrensis and the progenitor taxa in Wales.

Whatever the cause of the length mutation in the Welsh Senecio cambrensis it provides independent evidence for the dual origin of $S$. cambrensis in Wales and Scotland (Ashton \& Abbott, 1992) because in $S$. cambrensis from Scotland this mutation is absent. If the Scottish S. cambrensis had been the result of long distance fruit dispersal from Wales (Abbott et al., 1983) then the cpDNA ought to be identical to that of Welsh $S$. cambrensis. Of particular interest would be a survey of $S$. cambrensis from Mochdre, Wales because Ashton \& Abbott (1992) have suggested that this may represent a third site of origin of $S$. cambrensis.

\section{Acknowledgements}

We would like to thank J. D. Palmer (Indiana State University) for the gift of the Lactuca sativa cpDNA library and M. O'Dell (Cambridge Laboratory, John Innes Institute, Norwich) for the gift of the wheat ribosomal clone, pTA71. Thanks are also due to Richard Abbott, Paul Ashton, Judith Irwin and John Warren for collections of 'seed' material. This work was undertaken during the tenure of a NERC studentship to SAH.

\section{References}

ABBoTT, R. J., ASHTON, P. A. AND FORBES, D. J. 1992. Introgressive origin of the radiate groundsel, Senecio vulgaris L. var. hibernicus Syme: Aat-3 evidence. Heredity, 68, 425-435.

ABBotT, R. J., INGRAM, R. AND NOLTIE, H. J. 1983. Discovery of Senecio cambrensis Rosser in Edinburgh. Watsonia, 14, 407-408.

APPELS, R. McINTYRE, C. L., ClARKe, B. C. AND MAY, C. E. 1986. Alien chromatin in wheat: ribosomal DNA spacer probes for detecting specific nucleolar organiser region loci introduced into wheat. Can. J. Genet. Cytol., 28, 665-672.

ARNOLD, M. L., BENNETT, B. D. AND ZIMMER, E. A. 1990. Natural hybridization between Iris fulva and Iris hexagona: Pattern of ribosomal DNA variation. Evolution, 44, 1512-1521.

Ashton, P. A. 1990. Multiple origins of Senecio cambrensis Rosser, and related evolutionary studies in British Senecio. Ph.D. Thesis, University of St Andews.

ASHTON, P. A. AND ABBotT, R. J. 1992. Multiple origins and genetic diversity in the newly arisen allopolyploid species, Senecio cambrensis Rosser (Compositae). Heredity, 68, 25-32.

BIRKY, W. W., MARUYAMA, T. AND FUERST, P. 1983. An approach to population and evolutionary genetic theory for genes in mitochondria and chloroplast and some results. Genetics, 103, 513-527.

BLEYDEN, R. 1988. Molecular genetics of triazine resistance in Senecio vulgaris. Ph.D. Thesis, University of Cambridge.

CORDESSE, F, SECOND, G. AND DELSENY, M. 1990. Ribosomal gene spacer length variability in cultivated and wild rice species. Theor. Appl. Genet., 79, 81-88.

CRISP, P. 1972. Cytotaxonomic studies in the section Annui of Senecio. Ph.D. Thesis, University of London.

DOYLE, J. J. AND DOYLE, J. L. 1987. A rapid DNA isolation procedure for small quantities of fresh leaf tissue. Phytochem. Bull., 19, 11-15.

DOYLE, J. J. AND DOYLE, J. L. 1988. Natural interspecific hybridization in Eastern North American Claytonia. Am. J. Bot., 75, 1238-1246.

DOYLE, J. J., DOYLE, J. L. AND BROWN, A. H. D. 1990. Chloroplast DNA polymorphism and phylogeny in the $\mathrm{B}$ genome of Glycine subgenus Glycine(Leguminosae). Am.J. Bot., 77, 772-782.

DOYLE, J. J., SOLTIS, D. E. AND SOLTIS, P. S. 1985. An intergeneric hybrid in the Saxifragaceae: evidence from ribosomal RNA genes. Am. J. Bot., 72, 1388-1391. 
DRUCE, G. C. 1927. The Flora of Oxfordshire. 2nd edn. Clarendon Press, Oxford.

FABIJANSK1, S., FEDAK, G. ARMSTRONG, K. AND ALTOSAAR, 1. 1990. A repeated sequence probe for the $\mathrm{C}$ genome in Avena (Oats). Theor. Appl. Genet., 79, 1-7.

FEINBERG, A. P. AND VogELSTEIN, B. 1983. A technique for radiolabelling DNA restriction endonuclease fragments to high specific activity. Anal. Biochem., 132, 6-13.

FLAVELL, R. B., O'DELL, M., THOMPSON, W. F., VINCENTZ, M., SARDONA, R. AND BARKER, R. F. 1986. The differential expression of ribosomal RNA genes. Phil. Trans. R. Soc. Lond. B., 314, 385-397.

FRANKEL, R., SCOWCROFT, W. R. AND WHITFIELD, P. R. 1979. Chloroplast DNA variation in isonuclear male-sterile lines of Nicotiana. Mol. Gen. Genet., 169, 129-135.

GALAU, G. A. AND WILKINS, T. A. 1989. Alloplasmic male sterility in AD allotetraploid Gossypium hirsutum upon replacement of its resident A cytoplasm with that of a $\mathrm{D}$ species G. harknessii. Theor. Appl. Genet., 78, 23-30.

GERLACH, w. L. AND BEDBROOK, J. R. 1979. Cloning and characterisation of ribosomal RNA genes from wheat and barley. Nucl. Acids Res., 7, 1869-1885.

HARLAND, S. c. 1954. The genus Senecio as a subject for cytological investigation. Proc. Bot. Soc. Br. Isles., 1, 256-257.

HARRIS, S. A. 1990. Molecular systematic studies in some members of the genus Senecio L. (Asteraceae). Ph.D. Thesis, University of St Andrews.

HATTORI, J., GOTTLOB-McHUGH, S. G. AND JOHNSON, D. A. 1987. The isolation of high-molecular weight DNA from plants. Anal. Biochem., 165, 70-74.

HUTCHESON, K. 1970. A test for comparing diversities based on the Shannon formula. J. Theor. Biol., 29, 151-154.

INGRAM, R., WEIR, J. AND ABBOTT, R. J. 1980. New evidence concerning the origin of inland radiate groundsel, $S$. vulgaris L. var. hibernicus Syme. New. Phytol., 84, 543-546.

IRWIN, J. A. 1990. Male competition and outcrossing rate in a hermaphrodite plant. Ph.D. Thesis, University of $\mathrm{St}$ Andrews.

JANSEN, R. K. AND PALMER, J. D. 1987. Chloroplast DNA from lettuce and Barnadesia (Asteraceae): structure, gene localisation and characterisation of a large inversion. Curr. Genet., 11, 553-564.

JORGENSEN, R. A. AND CLUSTER, P. A. 1988. Modes and tempos in the evolution of nuclear ribosomal DNA: new characters for evolutionary studies and new markers for genetic and population studies. Ann. Miss. Bot. Gard., 75, 12381247.

KENT, D. H. 1956. Senecio squalidus L. in the British Isles. 1. Early records (to 1877). Proc. Bot. Soc. Br. Isles., 2, 115-118.

KLEKOWSKI, E. J. 1988. Mutation, Developmental Selection and Plant Evolution. Columbia University Press, New York.

McINTYRE, C. L., ClARKE, B. C. AND APPELS, R. 1988. DNA sequence analysis of the ribosomal spacer regions in the Triticeae. Plant Syst. Evol, 160, 91-104.

MONAGHAN, J. L. AND HULL, P. 1976. Differences in vegetative characteristics among four populations of Senecio vulgaris L. possibly due to interspecific hybridization. Ann. Bot., 40, 125-128.

MURAl, K. AND TSUNEWAK1, K. 1984. Intraspecific variation of chloroplast DNAs (ctDNAs) in Aegilops triuncialis and geographical distribution of cytoplasmic types. Jpn. J. Breed. (Suppl)., 34, 280-281.

PALMER, J. D. 1986. Isolation and structural analysis of chloroplast DNA. Meth. Enzymol., 118, 167-186.

PALMER, J. D. 1987. Chloroplast DNA evolution and biosystematic uses of chloroplast DNA variation. Am. Nat., 130, 6-29.

PALMER, J. D., SHIELDS, C. R., COHEN, D. B. AND ORTON, T. J. 1983. Chloroplast DNA evolution and the origin of amplidiploid Brassica species. Theor. Appl. Genet., 65, 181-189.

RIESEBERG, L. H., BECKSTROM-STERNBERG, S. AND DOAN, K. 1990. Helianthus annuus ssp. texanus has chloroplast DNA and nuclear ribosomal RNA genes of Helianthus debilis ssp. cucumerifolius. Proc. Natl. Acad. Sci., U.S.A., 87, 593597.

RIESEberG, L. H., SOlTiS, D. E. AND PALMER, J. D. 1988. A molecular reexamination of introgression between Helianthus annuus and $H$. bolanderi (Compositae). Evolution, 42, 227-238.

ROSSER, E. M. 1955. A new British species of Senecio. Watsonia, 3, 228-232.

SCHAAL, B. A., LEVERICH, W. J. AND NiCTO-SOTELO, J. 1987. Ribosomal DNA variation in the native plant Phlox divaricata. Mol. Biol. Evol., 4, 611-621.

SOLTIS, D. E. AND SOLTIS, P. S. 1989. Allopolyploid speciation in Tragopogon: insights from chloroplast DNA. Am. J. Bot., 76, 1119-1124.

SPRINGER, P. S., ZIMMER, E. A. AND BENNETZEN, J. L. 1989. Genomic organisation of the ribosomal DNA of sorghum and its close relatives. Theor. Appl. Genet., 77, 844-850.

STACE, C. A. 1977. The origin of radiate Senecio vulgaris $\mathrm{L}$. Heredity, 39, 383-388.

TALBERT, L. E., DOEBLEY, J. F., LARSON, S. AND CHANDLER, V. L. 1990. Tripsacum andersonii is a natural hybrid involving Zea and Tripsacum: Molecular evidence. Am. J. Bot., 77, $722-726$.

TAYLOR, L. 1984. The potential for introgression in a British polyploid complex. Ph.D. Thesis, University of St Andrews.

TREMousaygue, D., GRellet, F., DELSENy, M., DELOURne, R. AND RENARD, M. 1988. The large spacer of a nuclear ribosomal RNA gene from radish: organisation and use as a probe in rape seed breeding. Theor. Appl. Genet., 75, 298-304.

ZIMMER, E. A., JUPE, E. R. AND WALBOT, v. 1988. Ribosomal gene structure, variation and inheritance in maize and its ancestors. Genetics, 120, 1125-1136. 